\section{UBC PETER A. ALLARD SCHOOL OF LAW}

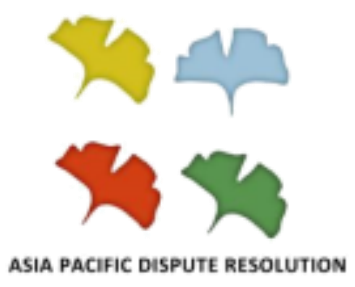

\title{
Learning Networks as a Tool for Good Governance: The Case of the Canada-China Forum on Industrial Relations and Employment Standards
}

\author{
Lorne Foster
}

York University

\begin{abstract}
APDR Working Paper Series Volume 4 Number 1
\end{abstract}

ISSN 2371-6304

(c) (i) (9) by Lorne Foster, 2017.

This article is made available as part of the Asia Pacific Dispute Resolution Working Paper Series and is licensed under a Creative Commons Attribution-NonCommercial- 


\title{
LEARNING NETWORKS AS A TOOL FOR GOOD GOVERNANCE: THE CASE OF THE CANADA-CHINA FORUM ON INDUSTRIAL RELATIONS AND EMPLOYMENT STANDARDS
}

\author{
Lorne Foster \\ York University
}

\section{Introduction to Public Policy Partnerships}

The forces of globalization in the twenty-first century are reshaping the 'policy space' 1 by fundamentally transforming the conditions for the organization of effective policy-making in both the national and international context (Meier, 1991; Kennett, 2008; Schwab, 2011). One development has been the emergence of 'governance' over 'government.' What government once did alone is now often being performed by a wide range of public, private, non-profit, and national and/or international bodies (Hirst and Thompson 1996: 184). Unlike government, governance extends beyond traditional politics and the simple workings of the machinery of the state, to embrace 'the stakeholder concept' (Schwab, 2011). Here, the emergence of global 'learning networks' (involving multilateral, multisectoral cooperation) is consistent with the increasing issue-complexity and interconnection of 'global modernity' (Dirlik, 2003). While we must take, with some caution, the argument that we have moved away from the political economy model of 'governing from the centre' (Savoie, 1999), there is growing evidence to suggest that we are witnessing an increasing trend toward shared or 'participatory governance' in many areas, involving the participation of corporate and civil society in the policy-making and administration processes (Pierre, 2000). So far, however, systematic knowledge about the public policy networks and partnership structures associated with modern governance is limited. We know only little about their dynamics and role in shaping globalization. The characteristics and functions of public policy networking, as well as its strengths and weaknesses in engaging globalization, deserve more comprehensive study (Benner, Reinicke and Witte, 2002).

This paper is a case study of the first Canada-China Forum on Industrial Relations and Labour Standards ('the Forum'), and seeks to address the issue of how organizations and social groups can challenge and engage globalization as a progressive social intervention. It explores the relationship between industrial relations development governance and global public policy

1 The term 'policy space' in common usage appeared in about 2002 in UNCTAD documents, and acquired its first official status in the São Paulo Consensus of 2004. This defined it as 'the scope for domestic policies, especially in the areas of trade, investment and industrial development,' which might be 'framed by international disciplines, commitments and global market considerations' (Overseas Development Institute, 2007). I use the term here also in a more generic public policy sense to refer to the agenda-setting system of global political economy - i.e., who gets to be involved in policy input, policy production, policy delivery and policy management. 
networking in terms of the rise of what Beck (2000) called a 'civil society international' - the civil society organizations, initiatives, and networks that transcend national borders yet whose strengths often reflect their local bases. Utilizing the literature on public policy networking, this paper will examine the transformative possibilities of learning netw orks as a catalyst for progressive social change.

The latent research hypothesis here is that learning networks are a component of participatory governance trends, and act as a structural adaptation to global modernity. In this important role, they are emerging as part of an entrepreneurial and innovative response, bringing together civil society, private businesses, international organizations and governments into coalitions for progressive change. These global public policy alliances have a flexible structure that at their best can react quickly to the challenges of globalization, evolving with the changing nature of the issues, and broadening the horizon of policy options. They not only bridge the growing distance among academics, policy-makers and citizens; they can also demonstrate that with the help of modern communication and outreach, successful knowledge transfer and collaborative action are serviceable in global society.

This paper seeks to test the hypothesis above, which can be formulated variously, as follows: a) In what ways, if any, can public policy learning networks be seen to be transformative?; b) In what ways, if any, can learning networks help promote and develop issuebased coalitions, acting as catalysts for innovation in governance?; c) In what ways, if any, can global learning networks democratize the debate on industrial and employment relations, and promote progressive social change?

\section{Project and Research Goals}

Benner, Reinicke and Witte (2002: 24-25) state that:

"Global public policy networks make an important contribution to the sustainable management of globalization. They complement and strengthen the existing forms of governance through the nation-state and international organizations ... When there is talk about politics, the focus is almost exclusively on the state. This narrow focus prevents us from turning to creative answers to the key political challenges of globalization and interdependence. The experience of global public policy networks can help to broaden the horizon of policy options."

China is currently seeking international expertise in a global dialogue on employment policy to make its transition from a planned to a market-based economy that includes building harmonious industrial relations more effectively. One step forward in this regard is China's recent ratification of International Labour Organization (ILO) Convention 111 on Discrimination Employment and Occupation (in 2006) and Convention 155 on Occupational Health and Safety (in 2007). A further step in the global dialogue is the initiation of a bilateral labour cooperation 
agreement between Canada and China for the purpose of strengthening capacity building and increasing cooperation in the areas of industrial relations and labour standards, and improving working conditions and living standards for workers in their respective counties.

Following the Chinese Minister of Labour's visit to Canada in 2006, the Canadian and Chinese Ministers of Labour signed a "Cooperation Framework between the Labour Program of Human Resources and Skills Development Canada and the Ministry of Human Resources and Social Security of the People's Republic of China in the Field of Industrial Relations and Labour Standards" in 2007 and renewed the Cooperation Framework in December 2009 for another three-year term. The objective of the Cooperation Framework is to strengthen respect for ILO fundamental labour principles set by the ILO, in conjunction with the 1998 ILO Declaration on Fundamental Principles and Rights at Work, which defines the "freedom of association and the effective recognition of the right to collective bargaining" as an essential right of workers. This agreement also resulted in the initiation of a Canada-China university partnership and coalition for learning on employment policy options. In addition, the long-term aim of the coalition is to establish the framework for a joint global public policy network for continued collaboration and best practices dialogue among Canadian universities, governments, businesses, unions and NGO communities and their Chinese counterparts in the years and decades ahead.

The first Canada-China Forum on Industrial Relations and Labour Employment was held on May 6 and 7, 2011, at the Beijing Conference Center, China. This project was sponsored by Canada's Ministry of Labour and the International Trade and Labour (ITL) Program. The additional support was provided by the institutional partners York Centre for Public Policy and Law (YCPPL), York University, Toronto, Canada and the Capital University of Economics and Business (CUEB), Beijing, China. The institutional partners were responsible for the assembly of the learning coalition delegates, comprised of academic, senior governmental, NGO, employer and union representatives from Canada and China.

The project goal of the Forum was to create a policy space where ideas and knowledge can be shared between academics, specialists, governmental bodies, employers, unions and others about how to work towards a sound employment agenda in the age of globalization. The program was designed to provide an opportunity for open dialogue among labour market stakeholders on the domestic issues and global challenges in the workplace with a particular focus on employment discrimination, tripartite mechanisms, labour dispute resolution and collective bargaining. The Forum sought to be informative, provide ample opportunity for participation and the exchange of information, and open constructive dialogue among international scholars and labour/ employment practitioners. It also provided participants with the chance to examine important comparative subject areas, including: the current standards and new developments in Canada and China with a view towards increased awareness of labour rights; employment and labour market governance; social security and employment promotion; socially responsible enterprise restructuring; health and safety standards; and worker rights and foreign trade linkages with the role that social partners play with workplace issues. Finally, the Forum provided an opportunity to consider how the respective roles of the state authorities, 
workers' and employers' organizations could adapt to better reflect the opening of the economy to market forces and the experience of other countries in applying the ILO Declaration on

Fundamental Principles and Rights at Work endorsed by the Canadian and Chinese governments.

The policy dialogue at the Forum was conducted as plenary panel discussions over a twoday period, in a comparative public policy format, utilizing simultaneous translation services. All delegates were engaged in the world of work around four subject areas:

1) Labour relations and labour issues.

2) Addressing employment discrimination.

3) Labour standards in the workplace.

4) Collective bargaining and collective consultation.

From China, 40 experts were drawn from Chinese universities as well as senior officials from the Chinese Ministry of Human Resources and Social Security and other relevant departments, from both central and provincial levels, the All-China Federation of Trade Unions, the China Enterprise Confederation, All-China Women's Federation, and labour NGOs. Experts from the International Labour Organization/Beijing Office were also invited.

From Canada, a 17-person multi-stakeholder delegation was assembled comprising of experts from: Canadian universities; senior officials from the International Trade and Labour Program, Human Resources Skills Development Canada, and relevant provincial departments; and labour relation experts from businesses, unions and NGOs, including Chinese and South Asian Legal Aid Center and the Multicultural History Society of Ontario. Canada's Ambassador to the People's Republic of China (PRC) also participated as a speaker in the Forum.

While recognizing that there are specificities in both countries, the major themes of the Forum issuing from bilateral and multisectoral discussions can be summarized as follows:

- New development of labor relationship research

- Safeguard for international cooperation and migrant workers

- Trend of changes in labor relationship

- Labor safety and labor protection

- How international labour legislations affect each country under globalization

- Tripartite negotiation mechanism and collective bargaining

- Labor disputes treatment

- Study of labor relations and trade union

- Study of moderate work and employment discrimination

- Theory and reality of labour mobility

- Wealth gap and choice of labour policy route

- Regional economics and moving trend of China's migrant peasants 
- Problems of urban employment difficulties

- Transformation of the economic development mode, employment and human resource management

- Promotion of equality at work, with a particular focus on migrant and gender equality as crosscutting themes

\section{Democratic Knowledge Mobilization and Good Governance}

Michael Mintrom (1997) noted that in the literature on policy innovation diffusion that little attention has been paid to how ideas for innovation gain prominence on government agendas. In his view, policy entrepreneurs constitute an identifiable class of political actors. Their presence and actions can significantly raise the probability of legislative consideration and approval of policy innovations. He concluded that by considering the actions of policy entrepreneurs - political actors who promote policy ideas - we can gain important insights into the process of policy innovation and innovation diffusion.

Policy entrepreneurship is a decided goal of the YCPPL, and is grounded in an ideological framework for democratic knowledge mobilization and good governance. The YCPPL is committed to knowledge-based relationships and coalitions for learning as a democratizing process that facilitates the reciprocity and exchange of ideas on policy issues and new instruments for learning over time about how to develop innovative public policy. Collaterally, these networks help consolidate pluralist and democratic administrations/societies by allowing the different actors (the "users" of knowledge) to take part in defining public policies, not merely in implementing them.

The major finding with respect to this ideological linkage for democratic knowledge mobilization and good governance is that the learning experience of Canada-China Forum elicited 'positive pluralism' results that were not completely anticipated. The Conference Evaluation responses and other indicators among Chinese delegates suggest that the Forum represented the first occasion where all of the Chinese experts from various epistemic communities with different interpretive perspectives had the opportunity to come together to discuss Chinese employment policy in an extended fashion. Hence, the most important outcome of the Forum's learning network experience was not the increased sharing of information and best practices between countries, but rather among the cross-sectoral 'interpretive and epistemic communities'2 (Haas, 1992) of both countries. This unexpected outcome could have dividends if it translates into the increased desire and/or opportunity for continued 'high-level' national and international discourse. This would also justify continued investments to build international

2 I use the terms 'interpretive communities' and 'epistemic communities' interchangeably to refer to a cohort of professionals with recognized expertise and competence in a particular domain and an authoritative claim to policy-relevant knowledge within that domain or issue-area (for reference, see Haas, 1992). 
learning networks that allow local researchers to access a greater exchange of outlooks and knowledge from indigenous epistemic communities, and from the 'global marketplace of ideas'.

Often, when people talk about globalization and public policy, the sort of pattern they are looking for is a substantial convergence or similarity in public policy across countries (Jacobs, 2011). Unlike these narrow policy approaches that involve simply imposing one-size-fits-all employment standards across countries, the Canada-China employment policy dialogue was premised on finding policy solutions that fit the jurisdiction where they are being applied. Participants in the Canada-China Forum joined the dialogue hoping to learn from their counterparts in other jurisdictions and from international institutions about employment standards and policies in ways that could be translated and applied in their own particular context. In the case of the Canada-China Forum, where Chinese delegates came together in significant numbers for the first time, we also found that the internal cultural discourse intensified cross-sector dialogue and deepened comprehension of the issues. Here, exposure to the different epistemic communities and interpretive perspectives within the national/domestic discourse is equally (if not more) important to the enrichment of policy dialogue, as is the sharing of international ideas and best practices.

\section{The Tension Between Capital and Labour, Efficiency and Equity}

Despite the specificities of both countries, the Canada-China policy dialogue reflects a shared theoretic (or contextual understanding) of the fundamental tension between 'capital' and 'labour' - in the sense that capital is significantly more mobile in an open international environment, while labour remains relatively immobile. Here it should be noted that, under globalization, the forces of labour migration are continuing, but, are subject to increasing regulatory constraints within and without many regions (Foster, 2006). This can place 'labour' at a relative disadvantage, in that 'capital' can now employ 'labour' in different regions or countries, at lower cost and on a basis which can prejudice the continuing employment of workers in the originating country or region. (Consider, for example, market-liberalization in China is linked to internal migration/displacement figures estimated in the range of 120 to 200 million [Deshingkar and Grimm, 2005: 10]). In this respect, neoliberal market values and norms attendant to globalization are having a chilling effect on job security, employment equity, and social justice outcomes.

The capital-labour problem, complex in both Canada and China, is manifested in the antinomies between efficiency and equity, productivity and sustainability, modernization and justice. In China specifically, rapid economic success and growth have made market reforms more and more necessary, resulting in both the restructuring of state-owned enterprises and the official acceptance of private business. With the shift from a planned to a market-based economy, massive privatization has been accompanied by precarious labour conditions, and the closing down of state-owned enterprises have resulted in the unemployment of millions of 
workers. The wave of factory shutdowns together with rising worker awareness from recently enacted laws has led to a surge in protests, strikes and labour disputes coming before the courts.

According to 2008 statistics from the All-China Federation of Trade Unions (ACFTU), 40 percent of private-sector employees lack labour contracts. An ACFTU survey in 2009 found that 14.4 percent of workers were owed back pay, 10.3 percent higher than in 2007 and that 60.2 percent of workers worked overtime. Among them, those in labour-intensive and private enterprises worked an average of 51.8 and 53.16 hours per week respectively, but 37.6 percent of the workers had not received overtime pay in full. In addition, official government figures indicate that a total of 26 million workers have been laid off from state-owned enterprises in the last ten years. This massive displacement of people has lead to an unprecedented wave of migrant workers to many urban centres who are often subject to discrimination in the areas of wages, working hours, health and safety conditions, housing and access to education for their children, the violation of workers' legitimate rights, and illegal employment.

Due to poor working conditions, weak or absent social safety nets and massive lay-offs, labour disputes increased eightfold between 1994 and 2001. Meanwhile, media reports indicated that labour disputes had significantly increased in more recent years, in the wake of the global financial and economic crisis. A rash of factory strikes in 2010, most notably at manufacturing plants that make parts for Japanese cars, has cast a spotlight on working conditions in manufacturing hubs along China's coast. These labour disputes and protests have resulted in increased efforts by the Chinese government to deal with labour issues in the context of the communist party's vision of a “harmonious society" (hexie shehui 和谐社会). As a result, three new labour laws aiming at improving labour standards came into effective in 2008. The Labour Contract Law provides for a mandatory written contract to be signed between employers and employees and promotes the role of unions in negotiating collective agreements. It protects workers from being dismissed without cause. The Employment Promotion Law aims at promoting employment and prohibiting job discrimination. The Labour Dispute Mediation and Arbitration Law streamlines the system of arbitration and lawsuits by strengthening both the institution and process of labour dispute resolution; achieving labour settlements fairly and in a timely manner; lowering the burden on employees when safeguarding their legal rights; and simplifying the settlement process for labour disputes.

Some research suggests that new legislative advances are timely and well positioned within China's legislative landscape. After three decades of growing tension between labour and management, and in a wave of widespread labour protests for wage increases in China, both the Chinese leadership and ordinary people from all walks of life can sense an impending social and economic disaster. Workers now stage strikes and protest publically in an effort to have the government intervene. In the first half of 2010, frustration reached a crisis level with the suicide of ten young workers of the Taiwanese electronics giant Foxconn in Shenzhen, who jumped to their deaths from their dormitories. These tragic incidents, together with strikes at the Honda parts plant in Guangdong, triggered worker protests across China. Chinese government officials 
quickly called on employers to improve salaries and working conditions and local governments to raise the minimum wage.

In reaction, the Guangdong provincial government responded proactively by drafting legislation that would allow labour conflicts to be resolved peacefully within enterprises, without the need for government intervention. The provincial Regulations on the Democratic Management of Enterprises (广东省企业民主管理条例) would create a legally binding mechanism that provides workers with the rights to demand and negotiate for pay increases with management, and to demand talks with management on wages and work conditions. These Regulations signal that a discussion on the formation of grass roots based and democratically elected trade unions, and the development of collective bargaining is timely.

\section{The Learning Network Perspectives on Enterprise Performance and Worker Satisfaction}

Chinese delegate, Li Qi (Michael), of the School of Labour Economics, Capital University of Economic and Business, argues that the currency of collective bargaining in China is growing, but the country actually lacks an authentic bargaining process. He observes that collective bargaining in China is basically an 'order issue' by a higher authority. In his view, features of labour relations in China are similar to an actual tripartite relationship - of employee/ trade union/ government/ employer (with trade unions representing employees). But, in reality, the employees are not really included; they are left in the hands of the state-controlled unions under the umbrella of the ACFTU.

As a country in transition, China's capacity to harness employment relations is a key element in improving enterprise competitiveness and performance. In order to maintain workers' support and influence at the enterprise level, it will be necessary to build and maintain an active workplace union organization. However, the ACFTU has a monopoly on trade unionizing in China, and the creation of competing unions is illegal. Contemporary labour law in China is forcing most companies - including most foreign owned ones - to create an ACFTU chaptered trade union within them. Consequently, it is the sole national trade union federation of the PRC. As a tool of the government, ACFTU has been seen as not acting in the best interest of its members (workers), bowing to the government pressure on industry growth and not defending workers' rights. Hence, many analysts/observers join Professor Qi (including the International Confederation of Free Trade Unions, among others) and maintain the position that the ACFTU is not an independent trade union organization.

Chinese delegate, Qiu Xioping, of the Department of Labour Relations, Ministry of Human Resources and Society Security of the PRC, asserts that the lack of a significant 'labour' voice at both the enterprise and national levels allows employers to routinely impair the legal rights of labourers by terminating labour contracts, by eliminating provisions for overtime, and through poor labour conditions. In Xioping's view, the relationship between employers and employees has been prominent in terms of conflict between individual relations and collective 
bargaining relationships. He predicts that labour relations will undergo increasing conflicts moving forward as the demand for a more diversified labour force increases, and there is a corresponding demand by the new labour force for an increased sense of collective legal rights. Xioping calls for benchmark mechanisms and a clear time-table for the improvement of the standard employment contract. In this view, the building of harmonious relationships in Chinese society will depend upon the shift in focus from a purely economic growth model to a more balanced one that addresses such social issues as the gap between rich and poor, widespread environmental degradation, government and corporate corruption, and (above all) worker satisfaction including: 1) standardizing wages; 2) improving people living conditions; 3 ) improving health and safety standards; and 4) expanding/increasing the domestic focus.

The employment policy dilemma in China is often formulated by researchers and analysts in terms of a dichotomy between workers' desire for collective bargaining and the political resistance to free trade unions. The competitive pressures exerted by globalization are resulting in greater emphasis being given to improved workplace relations (through increased bipartite and tripartite consultation and cooperation) and higher-level contributions to enterprise performance from workers. With China's newly found position there is the urgent need for a market-based labour relations module to figure out how employees/unions can create a partnership in a transparent and fair system. The current emphasis on building strong bilateral relations between managers and workers/trade unions in China is focused on improving industrial relations by institutionalizing worker-involvement in decision-making through legislation requiring, among other things, setting up of labour-management committees, which have not worked entirely satisfactorily. A critical issue will be the extent to which trade unions can increase their profiles and influence through this process in order to give them voices and help them influence the way in which agendas are designed.

Chinese delegates of the Canada-China learning network consistently asserted that achieving and maintaining high levels of economic productivity is counter intuitive to China's traditional employment practice. Being 'globalization ready' in China in the coming decades is likely to require increased opportunities for Chinese worker involvement in decision-making, and a more democratic and independent representation for the workforce than currently exists. The global workplace remains potentially volatile and unpredictable without comprehensive workplace inclusion strategies and instruments directed to improving the flexibility and skills of the workforce, increasing the emphasis on communication, cooperation and trust between managers, workers and their representatives. Moreover, the embedding of an effective and reliable regime for worker's employment rights will also require action in the areas of policy, institutions, and workplace practices and associated capacity building. A re-examination of the roles of government and the social partners and of the relevance and scope of employment laws and other rules and practices will be necessary to acknowledge the realities of a more decentralized workplace environment, and the need for the norms of the system to move away from a regulatory to an increasingly facilitative role, while still providing appropriate protections 
for workers. A renewed commitment to tripartite action and a greater emphasis on bilateral relations will be critical in realizing these changes (Macdonald, 1997: 35).

\section{The Cultural Phenomenon of Balancing "the Productive" and "the Social"}

The topic of sound employment policies constitutes a global public policy dialogue framed by international agendas and conventions for managing inequality and accommodating pluralism. In this regard, global modernity is characterized by crosscutting market forces that are both universal and particular, associated with the pressures of economic interconnectedness and population hybridity. On the one hand, globalization presents different jurisdictions with different labour market challenges and problems, which are theorized through the particularity of national and cultural circumstances. The global policy dialogue is premised on finding policy solutions that fit the jurisdiction where they are being applied; and there is no substantial convergence or similarity in employment policy standards across countries, or a one-size-fits-all employment policy. On the other hand, in coping with the different labour market challenges caused by globalization, workplace inclusion strategies and other pluralist accommodations are also theorized in many countries as central to the dynamism and synergy required for an integrated labour market and a productive economy.

Throughout the learning experience of Canada-China Forum, Canadian and Chinese Exceptionalism remained in tacked, and there was no substantial transference of policy solutions and implementations across the two countries. Globalization has international industrial dimensions, which require local (or culturally specific) adaptations. This is consistent with the major (and unexpected) outcome of the Forum with respect to the linkage between democratic knowledge mobilization and representation of good governance. As mentioned earlier, CanadaChina learning network experience was not characterized by a significant increase in the sharing of information and best practices between countries, but rather among the distinctive interpretive and epistemic communities within both countries.

For instance, the Conference Evaluation Responses and other anecdotal indicators among Chinese delegates suggest that the Forum represented the first occasion where all of the Chinese experts from across the country have had the opportunity to come together to discuss Chinese employment policy in any extended deliberation. In this respect, the learning network yielded positive results in terms of knowledge mobilization and transfer, even though the strength of the transfer of knowledge was predominantly confined to a local base.

The impact of globalization is theorized through the particularity of national and cultural circumstances, but the topic of good governance remains the same. Relatedly, in Chinese context, strong unions are often seen as collective mechanisms for the protection and fulfillment of workers, while in Canadian context, strong unions are often considered an impediment to the 
actualization of individual potential in the workforce. 3 So, whereas unions tend to be theorized in China as a solution to the integration challenges of globalization, in Canada they are often theorized as the problem reflecting a different cultural focus between collective rights versus individual rights. At the same time, in Chinese and Canadian context, the good governance principles and sound economic policy in the global market place are dependent on integrating 'the social' and 'the productive'.

It was also recurrently acknowledged by Canadian and Chinese delegates that in coping with contemporary labour market challenges in either country, ensuring that the enforcement of the relevant laws has been found to be insufficient. Legislation often does not have detailed, ready-made provisions for complex situations. In addition to a strong legislative regime (which both countries now have), it is essential that an industrial relations policy framework has the capability to work through institutions, programs and practices that embrace workplace inclusion/integration strategies and instruments. Balancing 'the social' and 'the productive' through instruments of collective bargaining and social dialogue 4 is an important part of such a 'Made in China' policy framework.

The Balancing of "the Social" and "the Productive" in China

Dependent Variables

1) Decent Work

2) Equal Employment Opportunities for All

Independent Variables

1) Social Dialogue [Tripartite Relations]

2) Collective Bargaining/Consultation

In Chinese context, collective bargaining and social dialogue were consistently articulated as focal points for a constructive engagement with sound employment policy. In the Canadian context, the strategies were often associated with regulatory protection structures, such as employment equity, pay equity, affirmative action and diversity management. This divergence in employment policy standards reflects a Chinese and Canadian 'Exceptionalism' as it relates to culturally specific differences between a collective rights focus on the one hand, and an individual rights focus on the other. Whereas the 'Made in China' solutions to workplace challenges are often focused at the social organization level, the 'Made in Canada' solutions tend

3 Note that this is consistent with the literature on economic globalization that has documented evidence in Canada and other countries of the decline in unionism and erosion of traditional patterns of bargaining and workplace norms (see - Chaykowski and Giles, 1998; Yaw and Smith, 2002).

4 Social dialogue is defined by the ILO to include all types of negotiation, consultation or simply exchange of information between, or among, representatives of governments, employers and workers, on issues of common interest relating to economic and social policy (http://www.ilo.org/public/english/dialogue/themes/sd.htm). 
to reside at the individual level. At the same time, the strong analytic intersections around issues of employment standards indicate a convergence on the idea and framework for good governance - as it relates to principles of fairness and inclusive citizenship, and the effective linkages between progress and people.

The Balancing of "the Social" and "the Productive" in Canada

Dependent Variables

1) Decent Work

2) Equal Employment Opportunities for All

Independent Variables

3) Inclusivity Instruments [Employment Equity/ Affirmative Action]

4) Human Rights Commission/ Workplace Safety and Insurance Board/ Workplace Compensation Board

While recognizing the specificities of both countries, members of the Canadian and Chinese delegations consistently theorized the political economy challenges of globalization in the connection of workers to citizenship, and employment to rights, and they recommended that these intersections must be considered important parts of any effective governance of modern industrial relations development.

Social dialogue and collective bargaining are theorized as the primary best practices in redressing the local balance of power between Chinese 'capital' and 'labour', linking productivity and equitable participation. Social dialogue and collective bargaining redress the balance of power between 'capital' and 'labour' by strengthening respect for Chinese workers' fundamental labour principles and rights through the development and implementation of industrial relations policies that support fair and stable workplaces and contribute to improved working conditions and living standards for workers. This mutual labour relations challenge is not merely a matter of generating income. People's work means more to them than adequate income. At work, whether in wage employment or self employment, people experience fairness or unfairness, and their voice may be heard or ignored. In the context of shared ILO principles, the fair treatment and dignity to which people aspire in employment must be assured if it is to be decent work.5 Moreover, sound employment policies based on instruments of fairness and inclusive citizenship are both a competitive advantage and a tool for preventing the proliferation of labour disputes and wider social conflict. 6

${ }_{5}$ See - Decent Work Agenda, ILO, http://www.ilo.org/global/about-the-ilo/decent-work-agenda/lang-en/index.htm.

${ }_{6}$ See - OECD Report, China in the world economy: The domestic policy challenges, OECD, Paris, 2002. 
In the shared tension between capital and labour, efficiency and equity, sound employment policies must include constructive social dialogue. Giving people voice through social dialogue is an effective process for generating sustainable solutions to conflicts of interest at the workplace. In the words of the ILO's Discrimination (Employment and Occupation) Convention, 1958 (No. 111), a labour market that is free from discrimination in respect of race, colour, sex, age, religion, political opinion, national extraction or social origin, and that guarantees freedom of choice of employment is one where more productive job matches can be made. Finding the best ways to give expression to these basic worker rights is recognized by members of the Canada-China public policy network as an important cornerstone of China's employment policy in line with the ILO's Employment Policy Convention, 1964 (No.122), which China has ratified. In this context, the promotion of equality at work involves balancing "the social" and "the productive" through democratic employment principles and practices.

The overall dispositional findings of the Forum strongly indicate and support workplace fairness and inclusion strategies, particularly in the areas of collective bargaining and social dialogue, as central to the dynamic and synergy required for an integrated labour market and a productive economy. Within the global discourse on industrial and economic relations, combating the resource inequities associated with globalization is recurrently and widely acknowledged to be accomplished with inclusionary and democratic strategies. Workplace inclusion and decent work strategies have become a fundamental part of a global agenda for management and modernization even under the new 'financial crisis' austerity, which many national governments around the world are faced with in recent years. Strong analytic intersections from both the Canadian and Chinese delegations occurred and were organized around issues of fairness and inclusive citizenship - connecting workers to citizenship, and connecting employment to rights - and recommended that these intersections must be considered important parts of any sound industrial relations policy framework.

\section{Project Goals and Research Goal Findings and Recommendations:}

Clearly a learning network with a single forum cannot reflect fully the richness and diversity of China's recent experience. The purpose of the main project was to flag the issues, which need attention of policy makers to take into account international developments and social concerns regarding the deepened tension and antinomy between capital and labour; efficiency and equity. In this respect, it represents a small indication of the large public policy challenges in the twenty-first century global society. At a wider level, the academic and exploratory goal of the Canada-China learning network was to consider the ways in which globalization is reshaping public policy formation and the agenda-setting system in many jurisdictional regions, and inciting broad trans-jurisdictional coalitions of actors in the policy making process.

The following represents the specific findings of this paper regarding the relationship of the Canada-China learning network and participatory governance. 
Significant Findings and Conclusions of the Forum:

1) The Forum plenary sessions had many substantive presentations that resulted in high level discussions and learning on the part of both countries' delegations in support of the Canada-China Cooperative Framework and their compliance as members of the ILO and signatories to the1998 ILO Declaration on Fundamental Principles and Rights at Work.

2) The Forum bridged the normal distance among academics, policy-makers and citizens; and demonstrated that with the help of modern communication and outreach, successful knowledge transfer and collaborative action are useful for international industrial relations dialogue.

3) The Forum provided an opportunity for (Chinese) academics and experts to come together to discuss and share ideas with each other in ways that were not normally available to them.

(Note: Many Chinese delegates stated that the Forum was the first occasion they were able to get together with a wide cross-section of other Chinese experts to discuss Chinese employment policy in an extended and lively fashion).

4) The Canada-China Forum generated a cross-cultural engagement of multisectoral participants through the inherent structural tension between national and global interests that both informed and stimulated the discussion.

(Note: Many Chinese and Canadian delegates noted that being required to focus at the level of comparative public policy analysis - or 'cross-countries' and 'cross policies' approach - widened the parameters of the normal debate and increased the level of intensity and excitement).

5) Public policy discussions and analysis in the Canada-China Forum cut across national, institutional and disciplinary lines by creating valuable linkages to build on knowledge and providing a conducive framework for coherent and comprehensive deliberations on public policy.

(Note: Many Chinese and Canadian delegates noted that the Forum opened up new topics and new channel(s) for participation in the public policy formulation process.) 
6) The Forum policy dialogue was enriched by the synergies in both domestic discourses and the sharing of the global marketplace of ideas and best practices. It established links to local and national policy dialogues that allowed for nuanced and cross-cultural discussions.

(Note: Many Canadian delegates commented that the cross-sector and cross-cultural composition of the Forum helped to move them away from the select 'discipline-centred' knowledge focus of typical conferences and workshops, and forced them to consider a more 'collaborative' knowledge approach to the issues. This is an exciting 'new lens' for industrial relations policy.)

7) The Canadian NGO delegates articulated a facilitative (as opposed to regulatory) role in Canadian employment relations that excite possibilities for duplication in the Chinese context.

(Note: Many Chinese delegates expressed high regard for the pro-activity and versatility of the representatives from the Canadian NGO community and their service-provider presentations - i.e., suggesting the possibility of future Canada-China sector cooperation in areas of cross-strategies for programming, and in the improvement of interorganizational coordination, as well as effective supports and best practices in the areas of internal- and trans-migration populations.)

8) Exposure to the different epistemic communities and interpretive perspectives within the national/domestic discourse on employment policy is equally, if not more, important to the enrichment of policy dialogue regarding the sharing of international ideas and best practices.

(Note: This would seem to attest to the importance of a more 'collaborative' knowledge approach to the issues as an exciting new lens for industrial relations and employment policy.)

9) Knowledge-based relationships and coalitions for learning facilitate the reciprocity and exchange of ideas on policy issues and new instruments for learning over time about how to develop innovative public policy, and therefore, pave the way for progressive social change.

(Note: Chinese and Canadian delegates were enthusiastic about the opportunity to take part in the Forum and the prospect of a future public policy 'network' because they offer new venues for participation, as well as increase the number of participants in the public 
policy dialogue, which has implications for increased democratic input in public policy processes and meaningful innovations in governance.)

10) *A summary conclusion would suggest that the Chinese delegates learned more from each other than they did from Canadian experiences. While not initially anticipated, this is a highly positive outcome and should go forward, we can expect that it will widen the focus and scope of Chinese expertise and broaden the horizon of policy options. This result strongly supports the goals of the Cooperative Framework and warrants consideration of support and further funding.

Recommended Short and Mid-Term Activities Arising from the Forum:

- Sabbaticals for officials in think tanks, universities, foundations, etc.

- Membership of officials on boards of academic and other research institutions

- Internships for researchers and students

- Professorial and student exchanges

- In-service professional training regarding research management and evidence-based policy

- *Twining arrangements, particularly in the NGO sector, but also between government departments and research institutions (e.g., parliamentary fellows, shadowing schemes, etc.)

Recommended Mid and Long-Term Action Arising from the Forum:

I. Promote and facilitate more forums and workshops/events that include multisectoral participation, offering new opportunities for interested nongovernmental actors to share ideas, take part, and make proposals. This broadens the information base and creates awareness of local impediments to resolution implementation. Furthermore, it is conducive to transparency and accountability among officials and other principals, and it also fosters the democratization of the employment policy dialogue.

II. Promote and facilitate coalitions of learning, such as the China-Canada Forum as an innovative tool, bringing together civil society, private businesses, international organizations and governments in coalitions for knowledge mobilization and exchange. These issue-based alliances have a flexible structure that can react quickly to the challenges of globalization, evolving with the changing nature of the issue. As coalitions for change, they not only bridge the growing distance among policy-makers, citizens, NGOs, employers and unions representatives, they also reduce the national government 'footprint'. 
III. Promote and facilitate the use of modern communication and outreach in future events and workshops to facilitate successful collaborative knowledge transfer, coalitionbuilding and collaborative action.

IV. Promote and facilitate 'twining arrangements' or 'shadowing schemes' between community-based NGOs and the outreach-based NGOs in Canada. One of the significant differences and disparities in the employment integration systems in China and Canada highlighted in the Forum was the relative effectiveness of NGO outreach with vulnerable communities - i.e., they are characterized by their agility and activism in their unique role as a supplement to government services. Canadian NGO outreach at its best can be a useful form of advocacy in areas of social welfare, training, victim support, community awareness, etc.

V. Commission an 'impact analyses' to be prepared on the status of Cooperative Framework and international ILO regulation and conditions/obligations. This is a basic input to ensure that the countries can make reasoned decisions in the medium and long term.

\section{Build on the partnership success and maintain the momentum of the Canada-China Forum by supporting and funding a multisector learning 'Canada-China Network'.}

In order to be a truly effective intervention into the social justice outcomes of the global workplace, a public policy learning network would be required to be a fully comprehensive medium (i.e., 'applied public policy') capable of closing the gap between Chinese worker's desire for collective bargaining on the one hand, and the political resistance by the state and business to the right of forming free trade unions, on the other. The consensual view of research and Forum experience is that no global learning network in the area of employment policy is capable of yielding the applied public policy dynamism of this level and at this time. The nature of the 'pro-market orthodoxy' of political economy and associated power dynamics makes the proposition of a determinant public policy learning coalition uncertain and problematic, if not prohibitive.

However, the reflection of this case study suggests that there are ways to make learning networks more effective in terms of impacting equitable participation issues and social justice outcomes in global society. For instance, "Partnering Competency" or "Relational Contracting" skills are of crucial importance. Actors in networks need to be able to mediate between different sectors and actors as well as between different levels of organizations-local, regional, national, and global. Internally, organizations can promote change and learning by being smart about working with intermediaries and networks to broaden access to the potential beneficiaries of research, and increase organizational salience and potential agenda-setting 
influence. Some research suggests that linkages with think tanks, foundations and governance schools can aid significantly in this regard (Benner, Reinicke and Witte, 2002: 23).

Some other central elements of the influence agenda may illustrate the nature of the overall challenge:

Elements of a Global Public Policy Learning Network Agenda

1) Partnering Competency [or Relational Contracting] - refers to the institutional capacity and ability to effectively lead a team to the successful completion of its objectives.

2) Knowledge Mobilization [or Knowledge Transfer] - refers to the focus on putting available knowledge into active service to benefit society; a proactive process to ensure that knowledge, especially publicly funded, is informed by needs and reaches the intended audience (see Shields and Evans, 2008).

3) Early and Ongoing Involvement of Decision-Makers - in knowledge mobilization and knowledge transfer is critical to effective government utilization of research.

4) Community Engagement - refers to cross-sectoral partners or community-researcher collaborations fostered for the mutually beneficial exchange of knowledge and resources [that address pertinent societal issues, build community capacity, enhance learning and discovery, strengthen democratic values and civic responsibility, and prepare educated and engaged citizens].

5) Collaborative Knowledge-Based Research - researchers or research facilities come together to pool their areas of expertise and combine their strengths for sophisticated and comprehensive analyses.

6) Build the Desired Outcome into Research Design - by accommodating policy makers and stakeholders during the research planning, not at the end when it may be too difficult to match the two.

7) Recognize Research and Decision-Making Linkages - are less of a product or event, but are on-going social processes. Research always takes place within a context of high complexity, multiple influences, and ongoing change. Therefore, researchers rarely exercise a decisive impact on policy agendas through the inherent force argument or evidenced-base work. There are not one but multiple paths to knowledge and a mix of juxtaposed realms of decision making that regulate themselves through a process of 
mutual adjustment. Evaluators have begun to take the policy-making system as their canvas.

8) User-Oriented Program Evaluation Approach - calling on the users throughout the study reduces the risk of the evaluation being socially irrelevant and increases the opportunities to ensure users define the areas of evaluation and modes of analysis. [No doubt involving users complicate life for the evaluation team, not only in terms of the time involved but also in ensuring methodological integrity. However, evaluation should never be done for its own sake, and the tradeoff is that user involvement dramatically increases the potential for influence and relevance, which are two of the most important goals in evaluation (see Vedung, 1997)].

9) Learning Partnerships - can only be sustained if the different cultures and interests of the partners are recognized and respected and where trust and equitable relationships are built into the partnering process.

10) Multi-Formatted Public Communication - influence is clearly seen as multi-path, uncertain and changing over time, yet project design is still a fundamentally linear process. Therefore, research has to reach all stakeholders, requiring it to be accessible in multiple formats in order to break down barriers that inhibit the use.

\section{Conclusion}

Delegates in the Canada-China Forum joined the public policy dialogue on industrial relations and employment standards hoping to learn from their counterparts in the other jurisdiction and from international institutions about employment policies and practices in ways that could be translated and applied in their own particular context. This result was consistent with the cross-cultural composition of the Forum. Meanwhile, members of both delegations also expressed enthusiasm regarding interactions with their fellows from their respective countries, as well as those from the other jurisdiction. These two findings likely indicate that the Forum structure provided cross-cultural dividends, and created synergies through the crosscutting forces of national and global interests, that both informed and intensified the learning experiences of participants on both sides. However, the major success of the Forum is that it served to bring a wide cross-section of Chinese experts and practitioner-specialists together in significant numbers for the first time. It appears the internal cultural discourse increased the excitement of Chinese learning network members, and intensified their cross-sector dialogue in a way that significantly deepened comprehension of the domestic issues. While some Chinese delegates expressed their admiration for the proactivity and versatility of the representatives from the Canadian NGO community (and their 'activist' service-provider orientation), a summary conclusion would suggest that the Chinese delegates learned more from each other than they did from Canadian 
experiences. While unexpected, this is a highly positive outcome that warrants the consideration of continued support for the public policy learning model in industrial relation areas and the continued pursuit of a networked governance agenda to move countries like Canada and China in progressive directions.

\section{Bibliography}

Beck, Ulrich. 2000. The Brave New World of Work. Malden, Mass: Polity Press.

Benner, Thorsten, Wolfgang H. Reinicke and Jan Martin Witte. 2002. "Shaping Globalization The role of global public policy networks." In Bertelsmann Foundation (eds.) Transparency: A Basis for Responsibility and Cooperation. Gütersloh, Bertelsmann Foundation Publishers.

Chaykowski, Richard and Anthony Giles. 1998. "Globalization, Work, and Industrial Relations." Relations Industrielles/Industrial Relations. 53:1:3-12.

Deshingkar, Priya and Sven Grimm. 2005. Internal Migration and Development: A Global Perspective. Geneva: IOM.

Dirlik, Arif. 2003. Global Modernity?: Modernity in an Age of Global Capitalism. European Journal of Social Theory. 6 (3): 275-292.

Foster, Lorne. 2006. "Foreign Credentials in Canada's Multicultural Society." In Stephen E. Bosanac and Merle Jacobs (eds.). The Professionalization of Work. Whitby, ON: de Sitter Publications, 282-335.

Haas, Peter M. 1992. "Epistemic Communities and International Policy Coordination.” International Organization. 46 (1): 1-35.

Hirst, Paul and Graham Thompson. 1996. Globalization in Question: The International Economy and the Possibilities of Governance. Cambridge, UK: Polity Press.

Jacobs, Lesley. 2011. "The Globalization of the Race Relations Policy Dialogue (Special Issue of Directions)." Directions: Research \& Policy on Eliminating Racism. 6 (2): 5.

Kennett, Patricia. 2008. Governance, Globalization and Public Policy. Northampton, MA: Cheltenham, UK: Edward Elgar. 
Macdonald, David. 1997. "Industrial Relations and Globalization: Challenges for Employers and Their Organizations" presented at the ILO Workshop on Employers' Organizations in AsiaPacific in the Twenty-First Century. Turin, Italy, 5-13. http://www.scribd.com/doc/2576739/INDUSTRIAL-RELATIONS-AND-GLOBALIZATION

Mintrom, Michael. 1997. "Policy Entrepreneurs and the Diffusion of Innovation." American Journal of Political Science. 41(3) (1997) 738-70.

Nelson, Jane. 2001. "Cooperation Between the United Nations and all Relevant Partners, in Particular the Private Sector.” Report of the Secretary-General A56/323. New York. http://www.un.org/partnerships/Docs/partnershipreport_a-56-323.pdf.

Newman, Janet. 2002. “The New Public Management, Modernization and Institutional Change: Disruptions, Disjunctures and Dilemmas.” In Kate McLaughin, Stephen P. Osborne and Ewan Ferie (eds.) New Public Management: Current Trends and Future Prospects. London: Routledge, 77-91.

Pierre, Jon. 2000. Debating Governance: Authority, Steering, and Democracy. Oxford: Oxford University Press.

Savoie, Donald. 1999. Governing from the Centre: The Concentration of Power in Canadian Politics. Toronto: University of Toronto Press.

Shields, John and Bryan Evans. 2008. Knowledge Mobilization/Transfer, Research Partnerships, and Policymaking: Some Conceptual and Practical Considerations. Policy Matters. No. 33 April.

Schwab, Klaus. 2011. "Challenge for Global Cooperation.” Huffington Post Business, May 20. http://www.huffingtonpost.com/klaus-schwab/challenge-for-global-coop_b_864179.html.

Vedung, Evert. 1997. Public Policy and Program Evaluation. London: Transaction Publishers.

Yaw A. Debrah and Ian G. Smith. 2002. Globalization, Employment and the Workplace: Diverse Impacts. New York: Routledge. 